ORIGINAL ARTICLE

ARTIGO ORIGINAL

\title{
Cost-minimization analysis of biological disease-modifying antirheumatic drugs in the Brazilian public health system (SUS) considering patients' weight
}

\author{
Análise de custo-minimização de medicamentos modificadores \\ de curso da doença biológicos no Sistema Único de Saúde \\ (SUS) no Brasil considerando o peso dos pacientes
}

Priscila Yuri Yazawa1*, Giovanna Renelo Puopolo²*, Juliana Walmrath', Rafael Leme-Souza², Juares Bianco ${ }^{3}$

DOI: 10.21115/JBES.v11.n2.p105-11

\section{Keywords:}

rheumatoid arthritis, tocilizumab, biologic DMARDs,

costs-minimization, weight dose dependency, cost analysis, public health system, Brazil

\begin{abstract}
Objective: To perform a cost-minimization analysis comparing the cohort with the current average patient weight of $70 \mathrm{~kg}$ (MoH current assumption). Since most rheumatoid arthritis (RA) patients in Brazil are women (60 kg or less), we also aimed to define this percentage at Brazilian public healthcare system (SUS). Methods: Treatment-naïve RA patients using biologics from January 2008 to November 2018 were retrieved from Datasus as well as the number of patients $\leq 60 \mathrm{~kg}$ and their drug use distribution. Data on drug costs were assessed from the last payment reported by $\mathrm{MoH}$ and then recalculated using the weighted average of $60 \mathrm{~kg}$ and a 52-weeks a year to assess cost-minimization. Results: In the studied cohort, 33,646 patients (33.3\%) were classified as $\leq 60 \mathrm{~kg}$. Annual cost per patient, considering an average weight of $60 \mathrm{~kg}$, ranged from 2,872,29 USD to 4,223.93 USD. Tocilizumab $80 \mathrm{mg}$ was the only drug demonstrating a reduction in annual cost per patient (-526.79 USD). Conclusion: Cost-minimization analysis based on weight-dependent dosage showed that tocilizumab could reduce $\mathrm{MoH}$ costs with RA treatment in 14.28\%. By adopting weight-dependent dose of $60 \mathrm{~kg}$, the Brazilian government could save up to 916,651.31 USD per year using tocilizumab versus other biological disease-modifying antirheumatic drugs (DMARDs). In ten years, it represents an accumulative saving of 9,166,513.57 USD.
\end{abstract}

\section{RESUMO}

Objetivo: Realizar uma análise de custo-minimização comparando a coorte com o peso médio de pacientes de $70 \mathrm{~kg}$ (atual premissa do Ministério da Saúde - MS). Como a maioria dos pacientes são mulheres ( $\leq 60 \mathrm{~kg}$ ), também se objetivou definir esse percentual no sistema público de saúde brasileiro (SUS). Métodos: Pacientes com artrite reumatoide (AR) virgens de tratamento utilizando biológicos de janeiro/2008 a novembro/2018 foram retirados do Datasus, assim como o número de pacientes com $\leq 60 \mathrm{~kg}$ e a distribuição de uso das drogas. Os custos dos medicamentos foram avaliados a partir do último pagamento relatado pelo MS e recalculados utilizando a média de $60 \mathrm{~kg}$ e um ano de 52 semanas para estimar a custo-minimização. Resultados: Na coorte estudada, 33.646 pacientes $(33,3 \%)$ foram classificados com $\leq 60 \mathrm{~kg}$. O custo anual por paciente, considerando o peso médio de 60 kg, variou de 2.872.29 a 4.223,93 USD. Tocilizumabe 80 mg foi o único que demonstrou redução no custo anual por paciente (-526,79 USD). Conclusão: A custo-minimização baseada em dose peso-dependente mostrou que o tocilizumabe poderia reduzir os custos do MS no tratamento de AR em 14,28\%. Ao adotar o peso de 60 kg, o governo poderia economizar até 916.651,31 USD ao ano utilizando tocilizumabe vs. outros medicamentos modificadores do curso da doença biológicos (MMCDb). Em 10 anos, isso representa uma economia acumulada de 9.166.513,57 USD.

Received on: 07/02/2019. Approved for publication on: 07/31/2019.

1. Roche Brasil - Produtos Roche Químicos e Farmacêuticos, Department of Specialty Care, São Paulo, SP, Brazil.

2. Roche Brasil - Produtos Roche Químicos e Farmacêuticos, Department of Access, São Paulo, SP, Brazil.

3. Roche Brasil - Produtos Roche Químicos e Farmacêuticos, Department of Medical Affairs, São Paulo, SP, Brazil.

* These authors contributed equally for this article.

Conflict of interests: The study was funded by F. Hoffmann-La Roche Ltd. and the authors are employees of F. Hoffmann-La Roche Ltd., São Paulo, SP, Brazil.

Corresponding author: Giovanna Renelo Puopolo. Av. Engenheiro Billings, 1729, Jaguaré, São Paulo, SP, Brazil. CEP: $05321-900$. Telephone: +55 (11) 3719-4674. E-mail: giovanna.puopolo@roche.com 


\section{Introduction}

Rheumatoid arthritis (RA) is an autoimmune, chronic inflammatory disease that primarily involves joints. However, extra-articular manifestations may also be observed, such as rheumatoid nodules, pulmonary involvement or vasculitis and systemic comorbidities. Clinical manifestations of the disease may include symmetrical polyarthritis, arthralgia, stiffness, erythema, movement loss, edema and even complete joint destruction (Smolen et al., 2007; Smolen et al., 2016). It is estimated that the disease prevalence ranges from 0.5 to $1.0 \%$ worldwide and from 0.2 to $1.0 \%$ in Brazil (Kvien, 2004; Marques Neto et al., 1993). It is estimated that the disease prevalence ranges from 0.5 to $1.0 \%$ worldwide and from 0.2 to $1.0 \%$ in Brazil (Kvien, 2004; Marques Neto et al., 1993).

The disease has a multifactorial characteristic, which results from the interaction between genetic and environmental factors and is most frequently observed among women with a peak of incidence at 50 years old (Alamanos \& Drosos, 2005; van der Woude \& van der Helm-van Mil, 2018). An increase in mortality rates is also observed among these patients when compared with healthy individuals, decreasing survival about three to ten years, depending on disease severity (Alamanos \& Drosos, 2005). Thus, disease generates important burden both to patients and society. The individual burden is related to musculoskeletal deficit, which produces a decline in both physical function, quality of life and the risk of comorbidities. The socioeconomic burden, beyond direct medical costs, is derived from patients' functional disability (Smolen et al., 2016; da Rocha Castelar Pinheiro et al., 2012).

Disease treatment is determined in accordance with the stage at diagnosis and aims to improve patients' quality of life, control the progression of joint lesions, prevent functional loss and decrease pain (Smolen et al., 2016). Therapy may involve the use of medications, non-pharmacologic therapies, consultations with specialists, complementary exams and several other procedures (Buendgens et al., 2013). Thus, an economic burden is also observed.

In Brazil, the estimated economic impact of the disease ranges from 19,860.16 Brazilian Real (BRL) to 5,889.13 BRL [2,423.51 American dollars (USD); using 2005 Brazilian currency; 1 USD $=2.43 \mathrm{BRL}$, considering all cost categories (Buendgens et al., 2013; Chermont et al., 2008; de Azevedo et al., 2008). Costs related to drug therapy represents $90.8 \%$ of total direct medical costs and $58.78 \%$ of all direct costs (Buendgens et al., 2013; Chermont et al., 2008). The public assistance is responsible for financing $73.6 \%$ of direct medical cost and $79.3 \%$ of drugs (Buendgens et al., 2013). According to the Organization for Economic Cooperation and Development (OECD), costs related to RA treatment are greater than health expenses per capita in several countries, including Brazil, when gross domestic product and health expenditures are analyzed. In the national scenario,
RA-related costs are almost twice (1.88) when compared to general health costs per capita (Chermont et al., 2008).

The Brazilian public healthcare system (SUS) provides RA treatment through the specialized component of pharmaceutical care (Silva et al., 2018). The Brazilian government published in November 2018 a document to regulate the availability of biological disease-modifying antirheumatic drugs (DMARDs) therapeutic schemes in accordance with the best cost-minimization profile. The definition of the best therapeutic option is though defined according to a cost-minimization analysis once the Clinical Protocol and Therapeutic Guidelines for RA recommend the alignment of all biological DMARDs after the failure of the first treatment, justified by the absence of statistically significant differences in efficacy and safety. The guidance is periodically reviewed by the Ministry of Health $(\mathrm{MoH})$, and new recommendations are published according to the cost-minimization profile. The last published list provides the following order: certolizumab Pegol 200 mg soluble injection; tofacitinib citrate 5 mg tablets; adalimumab $40 \mathrm{mg}$ soluble injection; abatacept $250 \mathrm{mg}$ powder for soluble infusion; etanercept $25 \mathrm{mg} / 50 \mathrm{mg}$ soluble injection; golimumab 50 mg soluble injection; rituximab 500 mg soluble injection; tocilizumab $80 \mathrm{mg}$ soluble injection; abatacept $125 \mathrm{mg} / \mathrm{ml}$ soluble injection; and infliximab $100 \mathrm{mg}$ powder for soluble infusion (Brasil, 2018).

Once some biological DMARDs for RA have weightdependent dosage, the weight pattern is an important factor in economic analysis and should be considered in cost-minimization. According to the MoH's technical note published in November 2018, the annual cost per patient is calculated based on a weighted average of $70 \mathrm{~kg}$ and a year with 48 weeks. However, the average weight of the Brazilian population (18-75 years old) is $70.7 \mathrm{~kg}$ and $60.9 \mathrm{~kg}$ for male and female individuals, respectively (IBGE, 2010). Most of RA patients in Brazil, including public and private healthcare systems, are females (86\% with an average weight of $62.5 \mathrm{~kg}$ ( \pm 3.9$)$. Male Brazilian RA patients have an average weight of $70.8 \mathrm{~kg}( \pm 16.1)$ (Souza et al., 2013; Louzada et al., 2007).

Considering that most Brazilian RA patients are female with an average weight of $60 \mathrm{~kg}$, this study aims to perform a cost-minimization analysis considering RA patients with $60 \mathrm{~kg}$ treated with tocilizumab. Furthermore, the study also aimed to estimate the number of patients $\leq 60 \mathrm{~kg}$ and to stratify them by drugs used in the temporal analysis.

\section{Materials and methods}

\section{Study design}

A descriptive analysis was conducted using secondary data available on the Brazilian National Health System Information Technology Department (Datasus). The study was conducted in accordance with local laws; however, since these data are electronically available, without subject's identification, there was no need for approval by a research ethics committee, neither did the patients have to sign an informed consent. 


\section{Study population}

Patients diagnosed with RA and in first-line of biologic DMARD treatment from January/2008 to November/2018 were retrieved from a database. The inclusion criteria considered all patients with the diagnosis of RA, using first-line biologic DMARDs from 2008 to 2018. Patients were excluded from analysis if the information about weight was not available on the database (ea: weight $\leq 1$ ) and when information on age and weight did not match (ea: 20 years and $540 \mathrm{~kg}$ ); these represented $19.1 \%$ of total patients in first-line treatment assessed during database analysis. An analysis was performed to estimate the number of first-line biologic DMARD treatment patients whose weight was equal or lower than $60 \mathrm{~kg}$, stratifying the sample by medication use across the time set.

\section{Database}

The Datasus is an electronic database that provides information on healthcare utilization that may be useful for health situation analysis, evidence-based decisionmaking and health assistance program development. Data on morbidity, disability, health access, life conditions and environmental factors are used to produce health indicators, which may be translated into relevant information to quantify and assess health information (Brasil, 2019b).

\section{Costs}

Drug costs were assessed through the last payment reported by Brazilian MoH (Brasil, 2019a). This analysis considered only the costs of medication use, excluding any other costs related to disease management.

Brazilian $\mathrm{MoH}$ calculates annual costs per patients considering a weighted average of $70 \mathrm{~kg}$ and a year with 48 weeks. For this analysis, drug costs were recalculated for the cohort of patients with a weighted average of 60 $\mathrm{kg}$ and a year with 52 weeks to assess a more realistic cost- minimization. Costs were converted into American dollars (USD), considering the average price for the period between 03/18/2019 and 05/16/2019 (1 USD = 3.91 BRL), according to Brazilian Central Bank (Banco Central do Brasil, 2019).

\section{Statistical analysis}

A descriptive analysis was conducted, using measures of central tendency and dispersion and measures of frequency. Patients were analyzed according to weight and age. The cohort of first-line biological DMARD treatment patients whose weight was equal or lower than $60 \mathrm{~kg}$ was isolated and stratified by medication use across the predefined time horizon.

\section{Results}

Extraction from Datasus database retrieved a total of 124,965 RA patients in use of biologics DMARDs from January 2008 to November 2018. Regarding gender, $79 \%$ were female and 21\% male (Table 1), 19.1\% were excluded due to eligibility criteria and $80.9 \%$ were analyzed.

From the eligible sample ( $N=101,058 ; 80,9 \%), 33.3 \%$ $(\mathrm{N}=33,646)$ were classified as having $60 \mathrm{~kg}$ or less. Gender distribution was different among all biologics except for tocilizumab where a female with $60 \mathrm{~kg}$ or less represented $38.2 \%$ of the patients and male, $37.4 \%$ (Table 2).

Annual cost analysis per patient using biological DMARDS has shown that annual expenses would be 2,872.29 USD for certolizumab 200 mg, 3,160.75 USD for tocilizumab, 3,176.09 USD for adalimumab, 3,236.20 USD for abatacept IV, 3,515.69 USD for rituximab, 3,580.83 USD for golimubab, 4,048.31 USD for tofacitinib, 3,875.14 USD for etanercept, and 4,223.93 USD for abatacept SC $125 \mathrm{mg}$, considering an average weight of $60 \mathrm{~kg}$ and a 52-week period. Infliximab price could not be calculated due to the process of partnership for product

Table 1. Database retrieved from January 2008 to November 2018 for a total of RA first-line biological DMARD treatment patients treated with biological DMARDs on SUS

\begin{tabular}{|c|c|c|c|c|c|c|c|c|c|}
\hline \multirow[b]{2}{*}{ Product } & \multicolumn{3}{|c|}{ Full database } & \multicolumn{3}{|c|}{$\begin{array}{l}\text { Weight not available and age/ } \\
\text { weight not matched }\end{array}$} & \multicolumn{3}{|c|}{ Total available for analysis } \\
\hline & Female & Male & Total & Female & Male & Total & Female & Male & Total \\
\hline Tocilizumab & 2,173 & 428 & 2,601 & 75 & 14 & 89 & 2,098 & 414 & 2,512 \\
\hline Certolizumab & 4,394 & 703 & 5,097 & 57 & 9 & 66 & 4,337 & 694 & 5,031 \\
\hline Etanercept & 28,354 & 8,124 & 36,478 & 5,208 & 1,991 & 7,199 & 23,146 & 6,133 & 29,279 \\
\hline Adalimumab & 39,398 & 10,606 & 50,004 & 7,876 & 2,392 & 10,268 & 31,522 & 8,214 & 39,736 \\
\hline Rituximab & 2,327 & 351 & 2,678 & 67 & 12 & 79 & 2,260 & 339 & 2,599 \\
\hline Abatacept & 2,345 & 348 & 2,693 & 78 & 9 & 87 & 2,267 & 339 & 2,606 \\
\hline Infliximab & 11,835 & 4,296 & 16,131 & 4,045 & 1,601 & 5,646 & 7,790 & 2,695 & 10,485 \\
\hline Golimumab & 7,838 & 1,428 & 9,266 & 405 & 66 & 471 & 7,433 & 1,362 & 8,795 \\
\hline Tofacitinib & 15 & 2 & 17 & 2 & 0 & 2 & 13 & 2 & 15 \\
\hline Total & 98,679 & 26,286 & 124,965 & 17,813 & 6,094 & 23,907 & 80,866 & 20,192 & 101,058 \\
\hline
\end{tabular}


development and the drug was placed in the last position of the ranking following $\mathrm{MoH}$ procedure in a technical note. The comparison of all biologics costs for patients with an average weight of $60 \mathrm{~kg}$ showed that only tocilizumab presented a price reduction (-526.79 USD; 14.28\% of reduction) (Table 3).

Table 4 shows the analysis of annual price and total expenses for the first-line biological DMARDs treatment of the sample assessed on a database with weight lower or equal to $60 \mathrm{~kg}$. Total costs in the period was 3,024,838 USD with tocilizumab ( $N=957), 4,059,355$ USD with certolizumab ( $N=$ 1,459), 40,479,675 USD with etanercept ( $N=10,446), 41,130,428$ USD with adalimumab ( $N=12,950), 3,150,060$ USD with rituximab ( $N=896), 2,660,159$ USD with abatacept $(N=822)$, 9,564,387 USD with golimumab ( $N=2,671)$ and 12,145 USD with tofacitinib $(\mathrm{N}=3)$. Infliximab price could not be calculated due to the process of partnership for product development.

\section{Discussion}

This study was conducted aiming to perform a costminimization analysis considering the cohort of RA patients with $60 \mathrm{~kg}$ or less treated with tocilizumab rather than more expensive treatment options. Thus, data on the pool of patients with this characteristic was obtained from the national database, and the simulations were performed using price strategy applied by the government.

The development of economic analysis for health technologies helps the decision-making process by weighing the relationship between clinical benefits and costs associated with their adoption. Four types of economic analysis are broadly used by the scientific community: costminimization, cost-benefit, cost-effectiveness and costutility (Silva et al., 2014; Secoli et al., 2010). Cost-minimization

Table 2. Total first-line biological DMARD treatment patients with weight lower or equal to $60 \mathrm{~kg}$ stratified by gender and biologic DMARDs

\begin{tabular}{|c|c|c|c|c|}
\hline \multirow{2}{*}{ Product } & \multirow{2}{*}{$\begin{array}{c}\text { Total (all weight) } \\
\text { All }\end{array}$} & \multicolumn{3}{|c|}{$\leq 60 \mathrm{~kg}$} \\
\hline & & Female (\%) & Male (\%) & Total (\%) \\
\hline Tocilizumab & 2,512 & 802 (38.2\%) & 155 (37.4\%) & 957 (38.1\%) \\
\hline Certolizumab & 5,031 & 1,369 (31.6\%) & 90 (13.0\%) & $1,459(29.0 \%)$ \\
\hline Etanercept & 29,279 & 8,885 (38.4\%) & $1,561(25.5 \%)$ & $10,446(35.7 \%)$ \\
\hline Adalimumab & 39,736 & 11,492 (36.5\%) & $1,458(17.8 \%)$ & $12,950(32.6 \%)$ \\
\hline Rituximab & 2,599 & 839 (37.1\%) & $57(16.8 \%)$ & 896 (34.5\%) \\
\hline Abatacept & 2,606 & 761 (33.6\%) & 61 (18.0\%) & 822 (31.5\%) \\
\hline Infliximab & 10,485 & $2,880(37.0 \%)$ & $562(20.9 \%)$ & $3,442(32.8 \%)$ \\
\hline Golimumab & 8,795 & $2,514(33.8 \%)$ & 157 (11.5\%) & $2,671(30.4 \%)$ \\
\hline Tofacitinib & 15 & $3(23.1 \%)$ & $0(0.0 \%)$ & $3(20.0 \%)$ \\
\hline
\end{tabular}

Table 3. Annual cost per patient, considering an average weight of $60 \mathrm{~kg}$ to calculate drug costs

\begin{tabular}{lccc}
\hline Drug & Annual cost per patient $\mathbf{6 0} \mathbf{~ k g}$ (USD) & Annual cost per patient 70 kg (USD) & Difference (USD) \\
\hline Certolizumab $200 \mathrm{mg}$ & $2,782.29$ & $2,782.29$ & 0 \\
\hline Tocilizumab $80 \mathrm{mg}$ & $3,160.75$ & $3,687.54$ & -526.79 \\
\hline Adalimumab $40 \mathrm{mg}$ & $3,176.09$ & $3,176.09$ & 0 \\
\hline Abatacept IV $250 \mathrm{mg}$ & $3,236.20$ & $3,236.20$ & 0 \\
\hline Rituximab $500 \mathrm{mg}$ & $3,515.69$ & $3,515.69$ & 0 \\
\hline Golimumab $50 \mathrm{mg}$ & $3,580.83$ & $3,580.83$ & 0 \\
\hline Etanercept $50 \mathrm{mg}$ & $3,875.14$ & $3,875.14$ & 0 \\
\hline Tofacitinib $5 \mathrm{mg}$ & $4,048.31^{*}$ & $4,048.31$ & 0 \\
\hline Abatacept SC 125 mg & $4,223.93$ & $4,223.93$ & 0 \\
\hline Infliximab $200 \mathrm{mg}$ & $* *$ & $* *$ & $*$ \\
\hline
\end{tabular}

USD: American dollars

All the values were calculated based on the MoH public information in January 2019.

* Tofacitinib price calculations don't consider taxes, as actually performed by $\mathrm{MoH}$.

** Infliximab price could not be calculated due to the process of partnership for product development. The drug was placed in the last position of the ranking as MoH procedure in technical note. 
Table 4. Total first-line biological DMARD treatment patients with weight lower or equal to $60 \mathrm{~kg}$, according to drugs used in the period, annual price and total expenses

\begin{tabular}{|c|c|c|c|c|}
\hline Drug & Count patient $-\leq 60 \mathrm{~kg}$ & Representativeness (\%) & Annual price (USD) & Total expenses (USD) \\
\hline Tocilizumab & 957 & 38.1 & 3,161 & $3,024,838$ \\
\hline Certolizumab & 1.459 & 29.0 & 2,782 & $4,059,355$ \\
\hline Etanercept & 10.446 & 35.7 & 3,875 & $40,479,675$ \\
\hline Adalimumab & 12.950 & 32.6 & 3,176 & $41,130,428$ \\
\hline Rituximab & 896 & 34.5 & 3,516 & $3,150,060$ \\
\hline Abatacept & 822 & 31.5 & 3,236 & $2,660,159$ \\
\hline Infliximab* & 3.442 & 32.8 & * & * \\
\hline Golimumab & 2.671 & 30.4 & 3,581 & $9,564,387$ \\
\hline Tofacitinib & 3 & 20.0 & 4,048 & 12,145 \\
\hline
\end{tabular}

USD: American dollars

* Infliximab price could not be calculated due to the process of partnership for product development and the drug was placed in the last position of the ranking as $\mathrm{MoH}$ procedure in the technical note.

analysis is the method chosen when treatment benefits are considered similar. Despite several publications and headto-head studies showing differences in treatment outcomes for biological DMARDs (especially in monotherapy, which represents up to one-third of patients with RA), the Brazilian government works with the assumption of no difference in effectiveness and safety of the available technologies (Silva et al., 2014; Singh et al., 2010; Donahue et al., 2012; Donahue et al., 2018; Emery et al., 2018; Gabay et al., 2013).

In the Brazilian government context of RA treatment, biological DMARDs are used after failure of synthetic DMARDs (first stage of treatment). Regarding the choice among biological options, cost minimization strategy adopted by the $\mathrm{MoH}$ is reinforced by several health technology agencies worldwide that use this methodology to define the adoption of RA treatment (lannazzo et al., 2013). However, these agencies also consider the patient's profile and alternative treatment strategies to create exceptions to cost-minimization, which is followed in Brazilian $\mathrm{MoH}$ by the Clinical Protocol and Therapeutic Guidelines (PDCT - Protocolos Clínicos e Diretrizes de Terapêuticos da Artrite Reumatoide). Patients' weight analysis is relevant for cost-minimization approach for RA treatment in Brazil, regardless of cost-minimization effectiveness.

Previous cost analysis related to RA treatment in Brazil estimates the economic impact of the disease reaching almost 20,000 BRL, considering all costs categories, and the expenses related to drug therapies are the main cost driver (Buendgens et al., 2013; Chermont et al., 2008; de Azevedo et al., 2008). In this scenario, this study provides important information to help the decision-making process.

Cost-minimization analysis from the perspective of the Brazilian public healthcare system has shown that tocilizumab utilization by RA patients with weight lower or equal to 60 $\mathrm{kg}$ treated with more expensive strategies could promote an economy of 9,166,513.57 USD in a ten-year period. To the authors' knowledge, this is the first study to perform a costminimization simulation considering RA patients with $60 \mathrm{~kg}$ or less treated with tocilizumab from the perspective of the Brazilian public healthcare system. Other cost-minimization analyses for RA treatment were performed in countries like Spain, France, Greece and Mexico. However, only two studies included the use of tocilizumab in the analysis (Ariza et al., 2014; Fautrel et al., 2005; Pichardo-Piña et al., 2015; Fragoulakis et al., 2015).

Pichardo-Piña et al. (2015) compared the costs of treating RA with adalimumab to etanercept, abatacept, infliximab, tocilizumab, certolizumab pegol and golimumab in the private market of Mexico, in a five-year time horizon, assuming patients weight of $70 \mathrm{~kg}$. In this scenario, adalimumab has proved to be less expensive against considered alternatives (Pichardo-Piña et al., 2015).

Ariza et al. (2014) compared the cost of treating RA patients after the failure of methotrexate with subcutaneous abatacept versus other first-line biologic disease-modifying antirheumatic drugs, including tocilizumab, from the perspective of the Spanish healthcare system and a threeyear time horizon, also assuming a patient weight of $70 \mathrm{~kg}$. In this scenario, abatacept was shown to be less expensive when compared to all other alternatives (Ariza et al., 2014).

Differences observed on the results shown in the present study and analysis described by Pichardo-Piña et al. (2015) and Ariza et al. (2014) may be attributed to differences in healthcare systems. Another important difference is the statement of the patients' average weight. Pichardo-Piña et al. (2015) and Ariza et al. (2014) consider the average of $70 \mathrm{~kg}$ while in the present analysis the average of $60 \mathrm{~kg}$ is used. Some disease-modifying drugs are dosage-weight-dependent and this definition directly affects the results found in the estimation.

Tables 3 and 4 present an estimation of the cost-savings from $\mathrm{MoH}$ if using weight cost-minimization approach. 
In this hypothetical scenario, if these patients were treated with tocilizumab, a total of 28,745 patients would have used this treatment option and the government would have saved 9,166,513.57 USD in a ten-year period or 916,651.31 USD per year. Although infliximab was excluded from the analysis, it was placed in the last position of a technical note, ranking with greater costs. Thus, it is possible to estimate that savings could be even higher if these potential patients were treated with tocilizumab.

The analysis performed also corroborates the change of tocilizumab in the scale of cost-minimization at $\mathrm{MoH}$ list. Considering the treatment only for patients with an average weight of $60 \mathrm{~kg}$ (33.3\% of the RA patients), tocilizumab would be classified as the second biologic DMARD on the list with a price of 3,160.75 USD per patient per year. If we consider the total tocilizumab cost and $38.1 \%$ of patients ( $60 \mathrm{~kg}$ average) and $61.9 \%$ (70 kg average), tocilizumab would perform a new average price of 3,532.87 USD and would be the $5^{\text {th }}$ on the cost-minimization price list.

Despite the relevant findings of this study, some limitations need to be highlighted. Since data were obtained through a secondary database, it is subject to problems related to underreporting and filling errors. Furthermore, this analysis only considers the cost related to drug therapy, not the other important issues such as other sources of costs, health-related quality of life and patients' preferences. Another limitation is inherent in all economic analyses that are based on simulations, which may not reflect what occurs in real life.

Even the results are based on a hypothetical scenario, the study presents important results for further long-term cost assessments given the chronic nature of the disease.

\section{Conclusion}

The cost-minimization analysis showed that the adoption of a weight parameter by the Brazilian government for RA treatment could save 916,651.31 USD per year, accumulating a total saving of 9,166,513.57 USD in ten years if RA patients with $60 \mathrm{~kg}$ or less were treated with tocilizumab. Thus, tocilizumab has shown to be the only biologic DMARD that decreases the cost with weight analysis and may be a treatment option instead of using costlier treatment options.

\section{Acknowledgments}

We thank SENSE Company for its support with medical writing during the development of this manuscript.

\section{References}

Alamanos Y, Drosos AA. Epidemiology of adult rheumatoid arthritis. Autoimmun Rev. 2005;4(3):130-6.

Ariza R, Van Walsem A, Canal C, Roldán C, Betegón L, Oyagüez I, et al. Costminimization analysis of subcutaneous abatacept in the treatment of rheumatoid arthritis in Spain. Farm Hosp. 2014;38(4):257-65.
Banco Central do Brasil [Internet]. [cited 2019 May 17]. Available from: https:// www.bcb.gov.br/

Brasil. Controladoria Geral da União. Portal da Transparência do Governo Federal [Internet]. [cited 2019a Apr 6]. Available from: https://www.cgu. gov.br/assuntos/transparencia-publica/portal-da-transparencia

Brasil. Ministério da Saúde. Departamento de Informática do SUS (Datasus). Datasus [Internet]. [cited 2019b Apr 6]. Available from: http://datasus. saude.gov.br/

Brasil. Ministério da Saúde. Nota Técnica no 411/2018-CGCEAF/DAF/SCTIE/MS. Brasília: Ministério da Saúde; 2018.

Buendgens FB, Blatt CR, Marasciulo ACE, Leite SN, Farias MR. Estudo de custo-análise do tratamento da artrite reumatoide grave em um município do Sul do Brasil. Cad Saude Publica. 2013;29(Suppl 1):s81-91.

Chermont GC, Kowalski SC, Ciconelli RM, Ferraz MB. Resource utilization and the cost of rheumatoid arthritis in Brazil. Clin Exp Rheumatol. 2008;26(1):24-31.

da Rocha Castelar Pinheiro G, Khandker RK, Sato R, Rose A, Piercy J. Impact of rheumatoid arthritis on quality of life, work productivity and resource utilisation: An observational, cross-sectional study in Brazil. Clin Exp Rheumatol. 2012;31(3):334-40.

de Azevedo AB, Ferraz MB, Ciconelli RM. Indirect costs of rheumatoid arthritis in Brazil. Value Health. 2008;11(5):869-77.

Donahue K, Jonas D, Hansen R, Roubey R, Jonas B, Lux L, et al. Drug Therapy for Rheumatoid Arthritis in Adults: An Update. Comparative Effectiveness Reviews n 55. Rockville: Agency for Healthcare Research and Quality; 2012.

Donahue KE, Gartlehner G, Schulman ER, Jonas B, Coker-Schwimmer E, Patel SV, et al. Drug Therapy for Early Rheumatoid Arthritis: A Systematic Review Update. Comparative Effectiveness Review n²11. Rockville: Agency for Healthcare Research and Quality; 2018.

Emery P, Pope JE, Kruger K, Lippe R, DeMasi R, Lula S, et al. Efficacy of Monotherapy with Biologics and JAK Inhibitors for the Treatment of Rheumatoid Arthritis: A Systematic Review. Adv Ther. 2018;35(10):1535-63.

Fautrel B, Woronoff-Lemsi MC, Ethgen M, Fein E, Monnet P, Sibilia J, et al. Impact of medical practices on the costs of management of rheumatoid arthritis by anti-TNFalpha biological therapy in France. Joint Bone Spine. 2005;72(6):550-6.

Fragoulakis V, Vitsou E, Hernandez AC, Maniadakis N. Economic evaluation of anti-TNF agents for patients with rheumatoid arthritis in Greece. Clinicoecon Outcomes Res. 2015;7:85-93.

Gabay C, Emery P, Van Vollenhoven R, Dikranian A, Alten R, Pavelka K, et al. Tocilizumab monotherapy versus adalimumab monotherapy for treatment of rheumatoid arthritis (ADACTA): a randomised, doubleblind, controlled phase 4 trial. Lancet. 2013;381(9877):1541-50.

lannazzo S, De Francesco M, Gomez-Ulloa D, Benucci M. A review of cost-effectiveness evaluations as part of national health technology assessments of biologic DMARDs in the treatment of rheumatoid arthritis. Expert Rev Pharmacoecon Outcomes Res. 2013;13(4):455-68.

IBGE - Instituto Brasileiro de Geografia e Estatística. Antropometria e Estado Nutricional no Brasil 2008-2009. 2010.

Kvien TK. Epidemiology and burden of illness of rheumatoid arthritis. Pharmacoeconomics. 2004;22(2 Suppl 1):1-12.

Louzada P, Souza BDB, Toledo RA, Ciconelli RM. Análise descritiva das características demográficas e clínicas de pacientes com artrite reumatoide no estado de São Paulo, Brasil. Rev Bras Reumatol. 2007;47(2):84-90.

Marques Neto JF, Gonçalves ET, Langen LFOB, Cunha MFL, Radominski S, Oliveira SMC, et al. Estudo multicêntrico da prevalência de artrite 
reumatoide do adulto em amostras da população brasileira. Rev Bras Reumatol. 1993;33(5):169-73.

Pichardo-Piña C, Sánchez-Casillas J, Pozos-Espíndola J. Cost-minimization analyses of adalimumab compared with selective immunosuppressive cytokines blockers and inhibitors of tumor necrosis factor alpha indicated for the treatment of rheumatoid arthritis, psoriasis and Crohn's disease in the private market in Mexico. Value Health. 2015;18(7):A843.

Secoli SR, Nita ME, Ono-Nita SK, Nobre M. Avaliação de tecnologia em saúde: II. A análise de custo-efetividade. Arq Gastroenterol. 2010;47(4):329-33.

Silva EN, Galvão TF, Pereira MG, Silva MT. Estudos de avaliação econômica de tecnologias em saúde: roteiro para análise crítica. Rev Panam Salud Publica. 2014;35(3):219-27.

Silva GD, Andrade EIG, Cherchiglia ML, Almeida AM, Guerra Júnior AA, Acurcio FA. Perfil de gastos com o tratamento da Artrite Reumatoide para pacientes do Sistema Único de Saúde em Minas Gerais, Brasil, de 2008 a 2013. Ciênc Saúde Coletiva. 2018;23(4):1241-53.
Singh J, Christensen R, Wells G, Suarez-Almazor M, Buchbinder R, LopezOlivo $M$, et al. Biologics for rheumatoid arthritis: an overview of Cochrane reviews. Sao Paulo Med J. 2010;128(5):309-10.

Smolen JS, Aletaha D, Koeller M, Weisman M, Emery P. New therapies for treatment of rheumatoid arthritis. Lancet. 2007;370(9602):1861-74.

Smolen JS, Aletaha D, McInnes IB. Rheumatoid arthritis. Lancet. 2016;388(10055):2023-38.

Souza R, Fraga JS, Gottschall CBA, Busnello FM, Rabito El. Anthropometry assessment in the elderly: estimates of weight and height and agreement between BMl ratings. Rev Bras Geriatr Gerontol. 2013;16(1).

van der Woude D, van der Helm-van Mil AHM. Update on the epidemiology, risk factors, and disease outcomes of rheumatoid arthritis. Best Pract Res Clin Rheumatol. 2018;32(2):174-87. 